\title{
Thanatology under the perspective of ethics and bioethics: a systematic review
}

\author{
A tanatologia sob a perspectiva da ética e bioética: uma revisão sistemática \\ Tanatología desde la perspectiva de ética y bioética: una revisión sistemática
}

Caroline Pereira Modesto ${ }^{1 *}$, Ana Maria Lima Carneiro de Andrade ${ }^{1}$, Lucas Tavares Cruz de Albuquerque $^{1}$, Kevellyn Cruz Aguilera ${ }^{1}$, Taelis Araujo Granja ${ }^{1}$, Ana Beatriz Tavares Cruz de Albuquerque $^{2}$, Géssica Gomes Pereira Modesto ${ }^{3}$, Wine Suélhi dos Santos ${ }^{4}$, Cláudio Gleidiston Lima da Silva ${ }^{5}$, Djailson Ricardo Malheiro ${ }^{6}$.

\begin{abstract}
Objective: Clarify bioethical dilemmas and introduces the concepts of the various perspectives during the death process: patient with end-stage disease, dysthanasia, passive euthanasia, active euthanasia, assisted suicide, orthotoasia and kalotanasia. Methods: This is a systematic review whose data were extracted from the MEDLINE and BVS databases. In the first mentioned, the descriptors "thanatology" and "ethics" were used using the logical AND operator, which resulted in 45 articles, after refinement the sample registered 04 articles. In the second base, the search was performed with the same descriptors $(n=34)$, but only 12 were selected. Results: Stands out the concept of death, good death and terminality of life. In addition to exploring the ethical dilemmas, challenges and opportunities presented at death regarding dysthanasia, passive and active euthanasia, assisted suicide, orthopasia and organ transplantation. Final considerations: The conception of death is transformed over time, technological advances have allowed attempts to extend life and the introduction of ethical and bioethical impasses about the end of life.
\end{abstract}

Keywords: Bioethics, Ethics, Death, Thanatology.

\section{RESUMO}

Objetivo: Esclarecer os dilemas bioéticos e apresentar os conceitos das várias perspectivas durante o processo de morte: paciente com doença terminal, distanásia, eutanásia passiva, eutanásia ativa, suicídio assistido, ortotanásia e kalotanasia. Métodos: Trata-se de uma revisão sistemática cujos dados foram extraídos dos bancos de dados MEDLINE e BVS. Na primeira base de dados referida acima foram utilizados os descritores "thanatology" e "ethics" com o uso do operador lógico AND, que resultou em 45 artigos, após refinamento a amostra registrou 04 artigos. Na segunda base citada, a busca foi efetuada com os mesmos descritores $(n=34)$, mas apenas 12 foram selecionados. Resultados: Ressalta-se o conceito de morte, boa morte e terminalidade da vida. Além de explorar os dilemas éticos, desafios e oportunidades apresentados na morte a respeito da distanásia, eutanásia passiva e ativa, suicídio assistido, ortotanásia e transplante de órgãos. Considerações finais: A concepção de morte se transforma através do tempo, os avanços tecnológicos permitiram tentativas de prorrogação da vida e a introdução de impasses éticos e bioéticos sobre o término da vida.

Palavras-chave: Bioética, Ética, Morte, Tanatologia.

\footnotetext{
${ }^{1}$ Faculdade de Medicina Estácio de Juazeiro do Norte (ESTÁCIO FMJ), Juazeiro do Norte - CE.

*E-mail: carolinepmodesto@hotmail.com

${ }^{2}$ Faculdade de Medicina de Olinda (FMO), Olinda - PE.

${ }^{3}$ Faculdade de Ciências Humanas, Econômicas e da Saúde (FAHESA/ITPAC PALMAS), Palmas - TO.

${ }^{4}$ Hospital Dom Hélder Câmara (HDH), Cabo de Santo Agostinho - PE.

${ }^{5}$ Faculdade de Medicina do ABC (FMABC), São Paulo - SP.

${ }^{6}$ Universidade Federal do Ceará (UFC), Fortaleza - CE.
}

SUBMETIDO EM: 4/2020 


\section{RESUMEN}

Objetivo: Aclarar los dilemas bioéticos y presentar los conceptos de las diferentes perspectivas durante el proceso de muerte: paciente con enfermedad terminal, distanásia, eutanasia pasiva, eutanasia activa, suicidio asistido, ortotanásia y kalotanasia. Métodos: Esta es una revisión sistemática cuyos datos fueron extraídos de las bases de datos MEDLINE y VHL. En la primera base de datos mencionada, los descriptores "tanatologícos" y "éticos" utilizaron el uso del operador lógico AND, que dio como resultado 45 artículos, después del refinamiento la muestra registró 04 artículos. En la segunda base mencionada, la búsqueda se realizó con los mismos descriptores $(n=34)$, pero solo se seleccionaron 12. Resultados: Se enfatiza el concepto de muerte, buena muerte y fin de la vida. Además de explorar los dilemas éticos, los desafíos y las oportunidades que se presentan en la muerte con respecto a la distanásia, la eutanasia pasiva y activa, el suicidio asistido, la ortotanasia y el trasplante de órganos. Consideraciones finales: El concepto de muerte cambia con el tiempo, los avances tecnológicos han intentado extender la vida y han introducción de impases éticos y bioéticos en el final de la vida.

Palabras clave: Bioética, Ética, Muerte, Tanatologia.

\section{INTRODUCTION}

Human condition can be based on the verification of the consciousness of death, in which one the individual certifies his own finitude. Between the 16th and e 18th centuries, the Latin phrase memento mori, which means "remember to die", was recognized by the observation of tombs, jewels, church walls and paintings that constantly symbolized death and its perishing. During this time, under the important influence of Catholicism, death was associated with condemnation, a fear that was perpetrated throughout life if the individual violated some norm imposed by the Church (NOONAN E, et al. 2013). Death is part of the natural evolution of life, which, despite the attempts to extend it from the technologies used to increase longevity, can't be avoided (MOURA LVC, et al. 2018).

The Committee for the Definition of Death (1989), of Christian influence, characterizes death as the loss of integration and coordination of the person's physical and mental functions. According to Brazilian law, death would be the complete and irreversible suspension of vital functions (SALES-PERES A, et al. 2006). Death diagnosis, in its legal aspects, moved from the cardiorespiratory criterion to the encephalic. This change allowed a breakthrough in organ transplants, since it allowed a greater discussion with the family about the donation (SALES-PERES A, et al. 2006).

There was a change in the death process: dying has changed with the introduction of technologies and medical approaches that have developed behaviors to maintain people's lives to the point of achieving therapeutic insensitivity through veiled cruelty. These conditions are maintained to support the illusion of relatives that their sick family member is still alive (MÁRQUEZ OHD, 2009).

Today, people's "death" becomes more evident before it actually is, that is, before official brain death occurs. This is a consequence of the close relationship between life and the capacity for social interaction. In this way, "premature death" appears as the effect of being a terminal patient or of the aging process itself that removes the subject's autonomy and independence (GUTIÉRREZ-SAMPERIO, 2001).

In view of the diversity of interpretations and conceptions, the scientific study of death and the death process, the Thanatology, was elaborated. This science addresses science of death in multiple spheres: anthropological, social, psychological, economic, religious and moral. It maintains a close connection with bioethics in order to build a link between the biological sciences and humanity (GUTIÉRREZ-SAMPERIO C, 2001). Ríos MR (2017) conceptualizes the word bioethics, implemented in 1970, as a systematic science of human behavior, in health perspective and in the aspects of the individual's experience, and is weighted under moral values and principles.

Bioethics is based on four principles: autonomy, beneficence, justice and non-maleficence (RíOS MR, 2017). These principles help to respond to technological advances in the health field, which occur without any reflection, especially in those related to death. The main dilemmas of bioethics and death are euthanasia, dysthanasia and orthothanasia (GUTIÉRREZ-SAMPERIO, 2001). 
There are several formulations of the euthanasia concept, but focusing on accelerated death with medical assistance. Voluntary euthanasia is that one in which the patient, in full mental condition, requests to withdraw his life. Involuntary euthanasia occurs when the subject didn't authorize or reject his death because he wasn't asked about. The non-voluntary is practiced when family members or caregivers request the individual agreement that doesn't detain their physical or mental state. Active euthanasia is where death is practiced with the use of resources, while in the passive eutanásia the agreement is sentenced by the withdrawal or retention of the essential means to maintain life (MYSTAKIDOU K, et al. 2005).

Based on the technologies evolution to increase the longevity of human life, the concept of dysthanasia arises in the denial-to-death process in the Western society. Dysthanasia is characterized as a death that causes suffering to the individual by techniques of artificial prolongation, commonly of high cost and invasive, which doesn't allow a better life quality to the patient. This refusal practice to human finitude is transfigured because it motivates health professionals to resort to all methods for extending life, bringing a false sense of omnipotence (SILVA KCO, et al. 2012).

From this, this article aims to characterize the role of bioethics and ethics within Thanatology, since, according to Wittkowski et al. (2015) work on ethical and legal issues encompassed only $2 \%$ in the last 20 years, revealing a need for further studies and clarifications between death and ethics.

\section{METHODS}

It's a systematic review according to PRISMA protocol, whose data were extracted from MEDLINE (Medical Literature Analysis and Retrieval System Online) and VHL (Virtual Health Library) databases. In the fisrt database, the research was made on August 09, 2018 at 11:00 a.m. by the CAPES Portal (Coordination for Improvement of Higher Level Personnel) by Estácio de Sá University, due to the greater availability of complete and free articles. The descriptors "thanatology" [Mesh] and "ethics" [Mesh] were used with the use of the logical operator AND, resulting in 45 articles. The inclusion criteria were: a) English language; b) publications between 2001 and 2018; c) complete and free articles. The refined sample registered 11 articles, which were submitted to exclusion criteria defined by the authors. The exclusion criteria were: a) prefaces; b) book chapters; $c$ ) theses and monographs; d) discordant themes for this article's theme. As a result of the specifications, the publications were reduced $(n=08)$.

In the second database, the search was made on August 09, 2018 at 8:03 p.m. with the same descriptors $(n=34)$ and inclusion and exclusion criteria $(n=20)$. In addition to the exclusion criteria the duplication of articles within the same database and with MEDLINE, leaving a sampling of 12 articles. The research was reinforced on August 10 and 11, 2018, obtaining the same results.

\section{RESULTS}

A general summary of the articles included in the final sample is presented, in addition to the authors, year of publication, objectives and main conclusions (Table 1). 
Table 1 - Results.

Authors

(DAGI TF e

KAUFMAN R, 2001)

\begin{tabular}{c}
\hline (GUTIÉRREZ- \\
SAMPERIO C, \\
2001) \\
\hline (YOUNGNER SJ e \\
ARNOLD RM, \\
2001) \\
\hline
\end{tabular}

(TURNER, 2004)

(MYSTAKIDOU K,
et al., 2005)

\section{Objectives}

Analyze the possible equation of brain death to death.

Describe bioethics related to death: therapeutic incarnation or dysthanasia, passive and active euthanasia, assisted suicide, orthotanasia and organ transplantation.

Review the controversies about death, in an attempt to explain why they have remained unresolved in the academic community.

Describe the relationship between religious theological structures and biotechnological fantasies.

Understand of the visions and traditions surrounding the act of euthanasia contribute to a better understanding of the controversies attitudes and modern practices in vogue.

\begin{tabular}{cc}
\hline $\begin{array}{c}\text { (HERSHENOV, } \\
\text { 2006) }\end{array}$ & Address and reflect the different concepts of death. \\
\hline $\begin{array}{c}\text { (SALES-PERES A, } \\
\text { et al., 2006) }\end{array}$ & $\begin{array}{c}\text { Update to professionals, seeking to address issues of } \\
\text { diagnosis of death and its certification, legal aspects and } \\
\text { details. }\end{array}$ \\
\hline $\begin{array}{c}\text { (EVANS J, 2008) } \\
\text { Explore the technological transformation of birth and } \\
\text { death. }\end{array}$ \\
\hline
\end{tabular}

(RUIZ A, 2008) Clarify what is worthy death.
(MÁRQUEZ OHD, 2009)
A critical analysis of the figure of conscientious objection

is made as an expression of the conquest of new spaces of freedom in societies in continuous evolution.

\section{Main conclusions}

The definitions of death are based on subjective patterns, priorities and social conventions rather than on objective facts about the state of human physiology.

Today, people's "death" is becoming more evident before they really are, that is, official brain death, as the effect of a terminally ill person or from the aging process itself, which removes the autonomy and independence of the individual.

From the implementation of cardiopulmonary resuscitation techniques and the use of the mechanical ventilator, the guidelines adopted the concept of brain death.

Within the belief systems of transhumanists, post-humanists and other technology enthusiasts, biotechnology offers the prospect of prolonging life and (more fantastically) even immortality in this world.

Today, there are several formulations of the euthanasia concept, but focusing on accelerated death with medical assistance. Voluntary euthanasia is that one where the patient, in full mental condition, requests to withdraw his life.

What is needed are not different criteria for death, but only different criteria for ceasing to exist. When people cease to exist, it simply follows that they are no longer involved in the biological functions required by the sole criterion of death.

Death diagnosis, in its legal aspects, moved from the cardiorespiratory criterion to the encephalic. This change enabled a breakthrough in organ transplants.

The same life support systems that support patients in a coma, immobilized or sick, make babies with severe disabilities and many fetuses medically "viable".

The "right to die with dignity" is a widespread expression in the medical community and among health professionals, but its exemplification allows many interpretations.

Dying has changed with the introduction of technologies and medical approaches that have developed behaviors to maintain people's lives to the point of achieving therapeutic insensitivity through veiled cruelty.

REAS/EJCH | Vol.12(9) | e3734 | DOI: https://doi.org/10.25248/reas.e3734.2020 Página 4 de 10 
(MENEZES MB, et Sought to know if nurses identify dysthanasia as part of al., 2009) the final life process of terminally ill people admitted to an adult ICU (Intensive Care Unit).

\begin{tabular}{|c|c|c|}
\hline (HIGO M, 2012) & Examine Bauman's cultural theory of death & $\begin{array}{l}\text { As the meaning of death and cultural attitudes towards mortality change and } \\
\text { invent new formulas to survive the fears and anxieties associated with death. }\end{array}$ \\
\hline $\begin{array}{l}\text { (SILVA KCO, et al., } \\
\text { 2012) }\end{array}$ & $\begin{array}{l}\text { This article seeks to discuss denial to death and the } \\
\text { practice of therapeutic obstinacy. }\end{array}$ & $\begin{array}{l}\text { Dysthanasia is characterized as a death that causes suffering to the individual } \\
\text { by techniques of artificial prolongation, commonly of high cost and invasive. }\end{array}$ \\
\hline $\begin{array}{l}\text { (FLORIANI CA, } \\
\text { 2013) }\end{array}$ & $\begin{array}{l}\text { It analyzes the concept of good death that underlies the } \\
\text { modern hospice movement. }\end{array}$ & $\begin{array}{l}\text { The hospice movement that covers two care groups: palliative care and } \\
\text { hospice care, which can be understood as "good death" modalities. This } \\
\text { movement brings a new definition, still little known and distinct from euthanasia, } \\
\text { kalothanasia. }\end{array}$ \\
\hline $\begin{array}{l}\text { (NOONAN E, et al., } \\
\text { 2013) }\end{array}$ & $\begin{array}{l}\text { Analyze the changes in the consciousness of death in } \\
\text { different cultural moments and the media influence on this } \\
\text { consciousness. }\end{array}$ & $\begin{array}{c}\text { The human condition can be based on the realization of the consciousness of } \\
\text { death in which the individual certifies his own finitude. Death was associated } \\
\text { with condemnation, a fear that was perpetrated throughout life if the individual } \\
\text { violated some norm imposed by the Church. }\end{array}$ \\
\hline $\begin{array}{l}\text { (OROZCO- } \\
\text { GONZÁLEZ MA, et } \\
\text { al., 2013) }\end{array}$ & $\begin{array}{l}\text { Identify the knowledge and experiences of Nursing } \\
\text { students about the death of hospitalized patients. }\end{array}$ & $\begin{array}{l}\text { Due to the daily proximity to people who die in hospital environments, health } \\
\text { professionals should be better prepared for this experience, knowing how to } \\
\text { recognize the legal, ethical and bioethical aspects that are involved in this } \\
\text { process. }\end{array}$ \\
\hline (RASS R, 2014) & $\begin{array}{l}\text { Apply religion to the set of ethical principles compatible } \\
\text { with life. }\end{array}$ & $\begin{array}{l}\text { It is evident that the general meaning we choose to assign to our lives largely } \\
\text { determines the nature of our choices and the direction of our efforts. }\end{array}$ \\
\hline $\begin{array}{l}\text { (WITTKOWSKI J, } \\
\text { et al., 2015) }\end{array}$ & $\begin{array}{l}\text { Reflecting on developments in the thanatology field, the } \\
\text { study of dying and death. }\end{array}$ & $\begin{array}{l}\text { Thanatology involves a study field that supports modern and even postmodern } \\
\text { tendencies by embracing emerging scientific and spiritual interests. }\end{array}$ \\
\hline (RÍOS MR, 2017) & $\begin{array}{l}\text { Determine which aspects of Bioethics are related to } \\
\text { spirituality in patient management. }\end{array}$ & $\begin{array}{l}\text { The author conceptualizes the word bioethics, as a systematic science of } \\
\text { human behavior, in health perspective and in the aspects of the individual's } \\
\text { experience and is weighted under moral values and principles. }\end{array}$ \\
\hline $\begin{array}{l}\text { (MOURA LVC, et } \\
\quad \text { al., 2018) }\end{array}$ & $\begin{array}{l}\text { Identify the thanatology thematic in the curricular } \\
\text { components of Nursing graduation courses. }\end{array}$ & $\begin{array}{c}\text { The perception of the historical, psychological and social aspects of the } \\
\text { individuals in the death process reflects the whole course of their experience. } \\
\text { The thanatological study allows a greater link between health professional and } \\
\text { the patient. }\end{array}$ \\
\hline
\end{tabular}

Source: Modesto CP, et al., 2020.
They point to dysthanasia based on the inappropriate and excessive use of procedures with high cost technology in patients with advanced diseases and with no prospect of clinical recovery.

REAS/EJCH | Vol.12(9) | e3734 | DOI: https://doi.org/10.25248/reas.e3734.2020 Página 5 de 10 


\section{DISCUSSION}

The word Thanatology has its origin in the Greek terms thánatos (death) and logos (knowledge). This expression integrates health care and ethical and bioethical conceptions related to the state of death. The perception of the historical, psychological and social aspects of the individuals in the death process reflects the whole course of their experience. The thanatological study allows a greater link between health professional and the patient and his greater discernment with the perishing context (MOURA LVC, et al., 2018).

Thanatology involves a study field that supports modern and even postmodern tendencies by embracing emerging scientific and spiritual interests. Its manifestation was present to the detriment of the religion decline and the rise of the individual values of the Western community (WITTKOWSKI J, et al., 2015). This science covers the patient-caregiver/family in the course of death, either in the earliest or final stages. This coverage pretension is to bring the link between the patient and the caregiver closer, in order to improve the death quality. This fact develops the thanatology backbone characterized by the triad: psychotherapy, reason and spirituality (MÁRQUEZ OHD, 2009).

As for spirituality, many religious traditions support the faithful foundations of an afterlife, with the principle that human life does not end due to death. Religions offer beliefs that deny the purpose of life and the fragility of human beings only on an existential level (TURNER L, 2004).

In Western society, the object of discussion is based on the avoidance approach. The highlight of fear of condemnation has been converted to measures that increase longevity; the increase of timing techniques; and the apology of eternal youth, addressing the aesthetics and worship of the body, placing spirituality in the background with regard to health policies (NOONAN E, et al., 2013; WITTKOWSKI J, et al., 2015).

The study of death is faced with multiple characterizations about the finitude of life. Hershenov (2006) makes a conceptual reflection of death from two points of view. On the one hand, death is characterized as the suspension of the vital functions of the organism as a whole. On the other hand, the "non-biological sense is preponderant and death is defined by the suspension of mental capacities, "not thinking".

Already Orozco-gonzález MA, et al. (2013) ponders about death, investigated since the beginning of mankind as a process which can be analyzed in several aspects, among them is the personalist approach, which portrays death as a humanity product that must be considered from the point of view of the experience of individuals with perishing. Due to the daily proximity to people who die in hospital environments, health professionals should be better prepared for this experience, knowing how to recognize the legal, ethical and bioethical aspects that are involved in this process and should be trained for certain situations.

With the increase in modern medicine, death is no longer considered a natural process and is now identified as a pathological dilemma, which has made possible causes of human mortality a target for vigilance and interventions (HIGO M, 2012).

In general, the concept of death, before the 1970s, was based on irreversible cardiorespiratory arrest. From the unfolding of new technologies in search of continuity of life, patients previously clinically declared as dead after a cardiac arrest, have the possibility of being resuscitated minutes to hours after the last breath (RASS, 2014). From the implementation of cardiopulmonary resuscitation techniques and the use of the mechanical ventilator, the professional guidelines and hospital policies adopted a new definition of the specific moment of death, adopting the concept of brain death. In 1968, the Harvard Ad Hoc Committee legitimized brain death before the law and medical society (YOUNGNER SJ e ARNOLD RM, 2001).

The definition of brain death occurs when vital brain functions are no longer working. Encephalic death is corroborated by specific tests (DAGI TF e KAUFMAN R, 2001).

Advances in medicine and its technologies have made it possible for treatments and cures for certain diseases considered to be complex to progress in order to improve life expectancies, once considered bleak. From prospective studies, some harms resulting from these new techniques of high technological complexity for longevity were visualized, resulting in discussions about the guiding principles of Bioethics (Table 2) (SILVA KCO, et al., 2012). 
So, the central dilemmas of bioethical aspects are represented by: a) patient with end-stage disease; b) dysthanasia; c) passive euthanasia; d) active euthanasia; e) assisted suicide; f) orthotanasia and g) kalothanasia (GUTIÉRREZ-SAMPERIO C, 2001).

\section{Patient with end-stage disease}

Menezes MB, et al. (2009) establishes the patient with terminal disease as the one in which it's in advanced stage of its illness, in the absence of a possible favorable evolution of his condition in spite of the available therapeutic alternatives.

Despite the poor prognosis and association with exhaustion of possibilities of cure, the terminally ill patient is not synonymous with leaving the patient adrift or idly. Far from it, there are a series of procedures that can be offered both to the patient and his family, for example, psychological support, pain management and relief, reduction of discomfort (MENEZES MB, et al., 2009).

\section{Dysthanasia}

The term dysthanasia, also known as Obstination or Therapeutic Ferocity, is involved in major debates in the Bioethics' field. The word of Greek origin dis (remoteness) and thánatos (death) expresses an extension of the death process, with no expectation of improvement or cure, and no life quality of the individual submitted to futile treatments (MENEZES MB, et al., 2009).

Table 2 - Guiding principles of bioethics

\begin{tabular}{cc} 
Autonomy & $\begin{array}{c}\text { It's the freedom of the individual to dictate his actions against } \\
\text { circumstances over which he has discernment. In the death field, the } \\
\text { patient who is aware of its cause, is able to approve or not a treatment } \\
\text { that is proposed to him. }\end{array}$ \\
\hline Beneficence & $\begin{array}{c}\text { Provide benefit to seconds according to their possibilities. A health } \\
\text { professional assists the patient in the process of confrontating the } \\
\text { pathology. }\end{array}$ \\
\hline Justice & $\begin{array}{r}\text { Ensure fair and equal opportunities for all patients, without distinction } \\
\text { based on social, economic and cultural parameters. }\end{array}$ \\
\hline Non-maleficence & $\begin{array}{c}\text { Perform your functions and duties as health professionals without } \\
\text { causing harm to patients. It corresponds to the protocols of conduct for } \\
\text { an ordered clinical practice and should assure the patient more benefits } \\
\text { in detriment to the risks. }\end{array}$
\end{tabular}

Source: Ríos MR, 2017. Table constructed by the authors from the source cited.

It is a veiled inhumanity translated into diagnostic and therapeutic procedures that don't add to or benefit critical patients who, according to their clinical and prognostic history, are considered terminal or without recovery chances. The patient is subjected to harmful, invasive and futile measures that increase the damage, economic and moral expenditure (GUTIÉRREZ-SAMPERIO C, 2001).

Menezes MB, et al. (2009) point to dysthanasia based on the inappropriate and excessive use of procedures with high cost technology in patients with advanced diseases and with no prospect of clinical recovery. This practice favors the extension of suffering without benefit to the patient.

\section{Passive Euthanasia}

Euthanasia comes from the Greek eu, "good", and thánatos, "death", in the sense of good death. Passive euthanasia is characterized by the removal of disproportionate measures and maintenance of those proportionate. The first is characterized by futile actions that produce discomfort and pain without raising any favorable response. The second, on the other hand, is about ordinary measures and support such as food, hygiene, physiotherapy, hydration and palliation. Passive euthanasia may be required by the patient when conscious and guided or by relatives and caregivers (GUTIÉRREZ-SAMPERIO C, 2001). 


\section{Active Euthanasia}

It's the deliberate act of causing the death of the patient through the administration of medications or procedures that suspend the cardiac, respiratory and encephalic function. It's a rising practice in countries where active euthanasia is legally accepted as Australia, the Netherlands or states of the American Union (GUTIÉRREZ-SAMPERIO C, 2001).

In this situation, death occurs without suffering and through direct intervention, such as the administration of lethal injection of narcotics. It is an anticipatory conduct with an inevitable end (GUTIÉRREZ-SAMPERIO C, 2001).

\section{Assisted Suicide}

It is the decision of the patient in the end-stage or really painful illness in agreement with their relatives or caretakers to end their life. It differs from euthanasia because, in assisted suicide, the doctor and the health team are the intermediary of the end of life by offering the ways to attain death. In this situation, it'll be the patient who will activate the infusion pump with lethal, opiate and sedative drugs (GUTIÉRREZ-SAMPERIO C, 2001).

Sometimes there is a conceptual confusion between euthanasia and assisted suicide. In general and simplified, in euthanasia, the application of the medicine that led to the patient's death is done by the doctor, usually in lethal doses. In assisted suicide, on the other hand, it is the patient who selfadministers the drug, after the specialist prepares the medications and provides information on how to proceed with the act (GUTIÉRREZ-SAMPERIO C, 2001).

\section{Orthothanasia}

It comes from orto (right, fair right) and thánatos (death): characterized by a death designated as natural, without interventions, occurring in the correct period (FLORIANI CA, 2013). Refers to the death quality before the inevitable end. All measures are designed to avoid reckless behavior and procedures that don't benefit the patient and the introduction of ways that condition comfort such as palliative care, mobilization, food and cleanliness.

The possibility of choosing the process of dying presents itself firmly at the end of life. Requests not to resuscitate (DNR) are constituted by legal declarations of informed refusals of consent, and are being expressed more frequently, in order to avoid invasive procedures to support the end of life (EVANS J, 2008).

\section{Kalothanasia}

Kalothanasia's word comes from kalós (good, pretty) and thánatos (death), which means beautiful, noble and exemplary death, enters the scene of thanatology as a description of death that cooperates with the interpretation of orthothanasia, contributing to a better discernment about "good death". Kalothanasia is the expression of a third possibility of scenario, one in which the individual doesn't intend to continue his experience at all costs due to the non-recognition of the death reality, but also doesn't crave for an anticipated death due to the suffering that his pathology brings (FLORIANI CA, 2013).

The hospice movement is a modern care project for terminally ill patients that covers two care groups: palliative care and hospice care, which can be understood as "good death" modalities. This is conceptualized as a mild death, without prolongations, that doesn't bring too much suffering to the individual. It can be understood in two important situations from the historical point of view: when death occurs in the family and when it's provided with great collective action, with community participation (FLORIANI CA, 2013).

Palliative care enables a painless death process and has a considerable life quality for the patient. The purpose is to provide comfort and tranquility during dying without prolonging the duration of suffering. Resuscitation therapies or intensive treatments don't fit into this method (MENEZES MB, et al., 2009).

The "right to die with dignity" is a widespread expression in the medical community and among health professionals, but its exemplification allows many interpretations. What would a worthy death be like? It depends. A terminal patient with clinical symptoms that can be controlled and having his discomfort minimized, 
home as a safe and warm environment, among family and friends, would be a considerable option. On the other hand, a very sick patient, with intense pains, hemorrhages and respiratory insufficiency, requires ample medical assistance. In this way, it's emphasized that when there is no probability of prolonging and seeking life quality due to the impossibility of recovery, all efforts must revolve around the establishment and maintenance of the death quality (RUIZ A, 2008).

The choice of indications of conduct, introduction or suspension of procedures or medicines isn't only and exclusive responsibility of the physician, is a shared and ethical decision. Patients, when conscious and in full mental condition, family or responsible, health authorities, civil or judicial committees and hospital bioethics, contribute and participate in the decision to manage the unfolding of death (GUTIÉRREZ-SAMPERIO C, 2001). Silva KCO, et al. (2012) portrays a file entitled Guidelines on the Termination of Life-Substance Treatment and the Care of the Dying, documented in 1987 in the United States, which discloses the right to health professional don't be engaged in cases where the patient or his caregiver requests a treatment considered frivolous.

It is a fundamental and basic duty of the physician to clarify and prepare the situation for the family and the health team responsible for the patient, to point out that there is a person in transit until death and that this moment must be guided with dignity, justifiable conducts, use of medicines and proportional technology (RUIZ A, 2008).

\section{FINAL CONSIDERATIONS}

The conception of death has transmuted through time, space, religion and culture. In the same community there are several abstractions that involve the process of dying, death and postmortem. Despite technological advances in the medical field in recent decades, the Western answer to death remains dual, contradictory and dressmaking based on the avoidance approach. The biological aspect used by modern science for determining death shouldn't be individualized, since death is a social construction. Thanatology addresses death in a broad spectrum, from significations and conceptualizations to bioethical dilemmas about the termination of life.

\section{REFERENCES}

1. DAGI TF, KAUFMAN R. Clarifying the Discussion on Brain Death. Journal Of Medicine And Philosophy. 2001; 26: 503-525.

2. EVANS J. BEYOND ABORTION: the looming battle over death in the :culture wars ‘. Bioethics. 2008; 22: 379-387.

3. FLORIANI CA. Modern hospice movement: kalothanasia and aesthetic revivalism of good death. Revista Bioética. 2013; $21: 397-404$.

4. GUTIÉRREZ-SAMPERIO C. La bioética ante la muerte. Gaceta Médica do México. 2001; 137: 269-276.

5. HERSHENOV D. The Death of a Person. The Journal Of Medicine And Philosophy. 2006; 31: 107-120.

6. HIGO M. Surviving death-anxieties in liquid modern times: examining zygmunt bauman's cultural theory of death and dying. Omega, South Carolina. 2012; 65: 221-238.

7. MÁRQUEZ OHD. Conscientious objection, death and dying in terminal illnesses. Acta Bioethica. 2009; 15: 94-99.

8. MENEZES MB, et al. Dysthanasia: nursing professionals' perception. Revista Latino-americana de Enfermagem. 2009; $17:$ :443-448.

9. MOURA LVC, et al. Thanatology teaching in undergraduate Nursing programs. Revista Baiana de Enfermagem. 2018; 32: 1-11.

10. MYSTAKIDOU K, et al. The Evolution of Euthanasia and Its Perceptions in Greek Culture and Civilization. Perspectives In Biology And Medicine. 2005; 48: 95-104.

11. NOONAN E, et al. Return of the memento mori: Imaging death in public health. Journal Of The Royal Society Of Medicine. 2013; 106: 475-477.

12. OROZCO-GONZÁLEZ MA, et al. Nursing students knowledge and experiences on death of hospitalized patients. Enfermería Universitaria. 2013; 10.

13. RASS R. Foreword to Rethinking Mortality: exploring the boundaries between life and death. Annals Of The New York Academy Of Sciences. 2014; 1330: 5-6.

14. RíOS MR. Bioethical aspects from the personalist vision of spirituality in the management of people in the health area. Anales de La Facultad de Ciencias Médicas. 2017; 50: 25-50.

15. RUIZ A. Right to die with dignity? Biomédica. 2008; 28: 191-194.

16. SALES-PERES A, et al. Forensic tanatology: biological and legal aspects. Braz J Oral Sci. 2006; 5: 1198-1202. 
17. SILVA KCO, et al. Does the "no" to death offer the "yes" to therapeutic obstination? Revista de Enfermagem da Ufsm. 2012; 2: 442-448.

18. TURNER L. Biotechnology as religion. Nature Biotechnology. 2004; 22 : 659-660.

19. YOUNGNER SJ, ARNOLD RM. Philosophical Debates About the Definition of Death: Who Cares?. The Journal Of Medicine And Philosophy. 2001; 26: 527-537.

20. WITTKOWSKI J, et al. Publication Trends in Thanatology: An Analysis of Leading Journals. Death Studies. 2015; 39: 453-462. 